\title{
LinkedIn: el IAPH en la red con los profesionales
}

El Instituto Andaluz del Patrimonio Histórico ha inaugurado página en LinkedIn. Con su presencia en esta red social busca reforzar las relaciones con los profesionales e investigadores del patrimonio cultural, enriqueciendo el contacto que ya de hecho se mantiene a través de las cuentas de Twitter de formación y de orientación laboral, Facebook, Google+ y Youtube. Desde este perfil, el IAPH pretende promover grupos de debate profesionales donde se propicie la comunicación bidireccional.

Julio Rodríguez Bisquert | Centro de Formación y Difusión, Instituto Andaluz del Patrimonio Histórico

URL de la contribución <www.iaph.es/revistaph/index.php/revistaph/article/view/3486>

El IAPH ha inaugurado página en LinkedIn, una red social especializada que, según los datos publicados en el último trimestre de 2013, se ha convertido en la tercera red en número de seguidores activos al mes (aquellos que han entrado una vez al menos en los últimos 30 días), tras Facebook y Google+.

En este espacio se ofrece información relativa a las actividades propias organizadas por el IAPH y también a las de otras instituciones afines al patrimonio de las que se tenga constancia, para ser así una fuente de referencia. Además se pretende promover grupos de debate profesionales donde se propicie la comunicación bidireccional, porque toda institución que quiera estar al día no puede estar aislada de su entorno. En el momento actual, en el que se ha pasado de la comunicación unidireccional emisor-receptor a ese nuevo diálogo denominado en internet como 2.0, es fundamental adaptarse a esos cambios, sabiendo transmitir y comunicar, pero también sabiendo escuchar.

Las instituciones de patrimonio, muy volcadas actualmente en la interactuación con la sociedad, deciden en su plan de comunicación cómo y con qué usuarios se quieren relacionar, decantándose por unas redes sociales u otras. En el caso de LinkedIn vemos que no todas están presentes y que muchas de ellas, aunque sí tengan su página de empresa creada, no tienen ninguna actividad; son meras presencias físicas que, a pesar de ello, en el caso de las instituciones de renombre, cuentan con un buen número de seguidores por si algún día deciden comunicar algo, como por ejemplo: The Museum of Modern Art, Guggenheim Museum, Tate, Musée du Louvre, Musée d'Orsay, ICCROM.

En otros casos, al ser una red profesional, consideran su muro como un mero tablón de anuncios de convocatorias de trabajo de su empresa (Metropolitam Museum of Art, San Francisco Museum of Modern Art, Rijksmuseum).

Entre las instituciones patrimoniales que ejercen una labor comunicativa bastante más activa y participativa sobre sus noticias y actividades destacan principalmente las anglosajonas como Victoria and Albert Museum, The British Museum, English Heritage.

Y por supuesto, no podemos pasar por alto una de las funcionalidades más interesantes de LinkedIn: los grupos de debate, que son ese espacio de encuentro para reflexionar entre profesionales. En este sentido podemos destacar los siguientes relativos a patrimonio, en algunos casos son propiciados por instituciones y en otros de carácter independiente promovidos por profesionales: ICOM members, ICOMOS, Heritage Conservation/ Historic Preservation of the Built Environment Network, Friends of heritage, English Heritage, Patrimonio en línea, Patrimonio storico da salvare, Restauraciones del patrimonio arquitectónico.

Desde este nuevo espacio queremos poner en práctica, con vuestra colaboración, ese lugar de encuentro y debate con los profesionales. Os esperamos:

http://www.linkedin.com/company/instituto-andaluz-delpatrimonio-hist-rico 